\title{
Foreign Language Anxiety in Higher Education: A Practical Framework for Reducing FLA
}

\author{
Hamad H. Alsowat, PhD, Assistant Prof. \\ College of Education, Taif University, Taif, Saudi Arabia
}

doi: 10.19044/esj.2016.v12n7p193 URL:http://dx.doi.org/10.19044/esj.2016.v12n7p193

\begin{abstract}
This study aimed at investigating foreign language anxiety level and the factors affecting the anxiety among Saudi English major students at Taif University and exploring the impact of gender and academic level in this regard. It also examined the relationship between anxiety and language proficiency in the Saudi context. Two questionnaires, a modified version of FLCAS (Horwitz et al., 1986) and IFLAF, were administered to 373 English major students (205 male and 168 female). The results revealed that Saudi English major students had moderate level of anxiety. The highest provoking causes of students' anxiety were worrying about consequences of failing, forgetting things they knew and feeling uneasiness during language tests. The analyses of the variables related to foreign language anxiety revealed a significant negative correlation between language anxiety and language proficiency (grammar, speaking, writing, reading and GPA). Gender did not have a significant impact on foreign language anxiety in the current study. Finally, the academic level of students did not affect the level of anxiety indicating that all students, despite their academic level, suffer from the same level of anxiety. The study suggested an EFL practical Model to reduce the negative effects of anxiety. Suggestions and further research were presented.
\end{abstract}

Keywords: Foreign language anxiety, gender, academic levels, language proficiency, English major students, anxiety sources

\section{Introduction}

The growing interest in learning English language pushes Saudi Arabia to perform significant efforts in teaching English language beginning from the earliest stages of the formal education. In response to the demands of English language teaching for Saudi students, the government provides a lot of facilities; offers new curricula and prepares English language teachers, but these efforts have not fulfilled their purposes; where most of the students have poor English language proficiency. Learning a foreign language is a 
challenging (Horwitz, Tallon \& Luo, 2010) since it requires much time and effort, and is not always an easy and pleasant activity even for a language enthusiast (Lam, 2009). There are many variables which affect language learning such as cultural background, learning styles, motivation, beliefs, attitudes, etc. Affective or emotional factors, which have a significant importance in learning a language, play a vital role in language learning; and they may facilitate or impede language learning. One of the most important affective factors that affects language learning is Foreign Language Anxiety (FLA). The study of anxiety in second language learning started as a result of an upsurge of research into various individual learner differences anticipated to affect language learning success (Toth, 2007:123). Most language learners experience a feeling of anxiety in the process of language learning. The number of students who report that they feel anxious while learning a second/foreign language is surprising (Riasati, 2011). Moreover, language anxiety is experienced by one third to one half of foreign language learners (Worde, 1998). Therefore, foreign language teachers should be aware of foreign language anxiety inside classrooms to facilitate learning and motivate students to overcome this obstacle.

During the last five years, the relationship between anxiety and language proficiency, language skills and achievement has been examined. A large amount of research focused on exploring the anxiety level in learning English language and its relationship to some variables (e.g. Alrabai, 2014; Al-Saraj, 2014; Javid, 2014; Mahmoodzadeh, 2013). Other studies (e.g. Kamaruddin \& Abdullah, 2015; Lian \& Budin, 2014; Nahavandi \& Jayakaran, 2013) concentrated on the relationship between anxiety and achievement and language proficiency. Regarding the foreign language anxiety in learning the language skills separately, it has been found that many studies have been conducted to explore the relationship between foreign language anxiety and language skills as follows: Reading (e. g. Cabansag, 2013; Um, Tubsree \& Surasin, 2013; Ghonsooly \& Loghmani, 2012); writing (e.g. Jebreil, Azizifar, Gowhary \& Jamalinesari, 2015; Naghadeh et al.,2014; Rezaei \& Jafari, 2014); speaking (e.g. Yahya, 2013; Chiang, 2012), and listening (e.g. Baran-Lucarz, 2013; Serraj \& Noordin, 2013). These studies were conducted in different contexts, and their results showed conflict findings.

In the Saudi context, few studies have been conducted to investigate the anxiety of Saudi EFL learners. AlAsmari (2015) investigated the anxiety among preparatory year students at Taif University. The participants were 76 preparatory year students with high English language proficiency and 64 with low English language proficiency. The results revealed that Saudi EFL preparatory year students suffer from medium level of FL anxiety. The findings have not exhibited any significant differences in the perceptions of 
Saudi preparatory year students regarding FL anxiety in relation to their English language proficiency. At the elementary school level, Alshahrani \& Alandal (2015) investigated the level of FLA and the impact of gender differences among 146 male and 114 female $6^{\text {th }}$ grade Saudi students. The results showed that FLA was moderate and gender difference did not play a significant impact on anxiety towards foreign language learning. Alrabai (2014) also conducted a study to investigate the levels and sources of foreign language anxiety (FLA) among 1389 Saudi (male and female) EFL learners. The participants were of intermediate, high and university levels. The participating learners reported moderate to high levels of anxiety, with communication being the key cause of learners' language anxiety. Also, Javid (2014) identified Saudi EFL learners' anxiety and its causes of randomly-selected 216 freshmen male students enrolled in the preparatory year program at Taif University. The results reveal that Saudi preparatory year bear medium level of language learning anxiety. Among the four anxiety factors, communication apprehension anxiety remained at the top followed by English classroom anxiety. Fear of negative evaluation anxiety has been assigned the third position and test anxiety got the least average mean. Furthermore, Al-Saraj (2014) examined the anxiety level of 83 EFL female students - in a College Preparatory Program (CPP)using the Arabic Foreign Language Anxiety Questionnaire (AFLAQ). The study revealed that participants' average AFLAQ scores ranged from 1.80 to 4.30 out of 5.00; the mean score across participants in Level 1 was 3.33, Level 3 was 3.25 and Level 4 was 2.95. From a different aspect, Aljafen (2013) targeted the writing anxiety of 296 male students studying at the science departments at Qassim University in Saudi Arabia. The findings showed that students share almost the same moderate feeling of English writing anxiety and the weakness of their past English education was the first and overwhelming reason they gave for their writing anxiety, their lack of confidence in writing was the second, and the last one was the evaluation. Finally, Al-shalawi (2010) investigated the experience and perception of 60 Saudi male Arabic-speaking university students on English learning classroom anxiety. The results indicated that students experienced comparatively high anxiety in English learning.

\section{Statement of the problem}

Saudi students enter university with many English language problems. Since the academic context of university is different from public schools context, and English is used as a means of teaching at English language departments, most of students feel different kinds of foreign language anxieties. By understanding students' anxiety level and its relationship to gender, language proficiency and academic level, it is 
assumed that teachers can help their students to overcome this problem. Moreover, anxiety relationship to language proficiency will investigate the skills which students feel worry about.

As mentioned above, the research conducted in the Saudi context showed that only one study -Al-shalawi (2010)- dealt with foreign language anxiety of English major students at EFL departments since those students really face different kinds of anxiety. Also, the limited number of studies conducted in Saudi Arabia did not took gender into account to explore its impact on foreign language anxiety as Yang (2012) stated that research on the relationship between gender and language anxiety has led to conflicting findings. Moreover, some researchers reported a significant anxiety-gender effect, while others reported no relationship between the two variables. Also, this research will afford a practical framework for instructors to reduce anxiety consequences. So, this research comes to bridge the gap in the existed research by investigating the foreign language anxiety level of Saudi English major students at Taif University and exploring the impact of gender and academic level on foreign language anxiety. It also tends to find out the relationship between anxiety and language proficiency in the Saudi context. It is hoped that this study provides English language instructors with the most provoking factors that affect learning a foreign language, and helps students to overcome language anxiety to become better English language learners.

This study tends to answer the following questions:

1. To what extent do Saudi EFL students perceive foreign language anxiety?

2. What are the main factors that cause foreign language anxiety among Saudi EFL students?

3. Is there any statistically significant relationship between students' foreign language anxiety level and their language proficiency?

4. Are there any statistically significant differences between students' foreign language anxiety and factors affecting their anxiety related to gender?

5. Are there any statistically significant differences between students' foreign language anxiety and factors affecting their anxiety related to the academic level?

\section{Review of Literature}

\section{Definition and Types of Foreign Language Anxiety (FLA)}

The concept of foreign language anxiety (FLA) has been well established in sociolinguistic studies since the 1980s (Sharkawi, 2009). FLA is defined as the: 
"apprehension experienced when a situation requires the use of a second language with which the individual is not fully proficient. It is, therefore, seen as a stable personality trait referring to the propensity for an individual to react in a nervous manner when speaking, listening, reading, or writing in the second language" (Gardner \& Maclntyre, 1993:5).

Horwitz, Horwitz \& Cope (1986:128) looked at language anxiety from the language learning perspective; they pointed that language anxiety is "a distinct complex of self-perceptions, beliefs, feelings, and behaviors related to classroom language learning arising from the uniqueness of the language learning process". So, foreign language anxiety has two folds: the first one comes as the result of the situations in which the learners use the and learn the language and the second arises from the nature of the language itself.

Horwitz et al. (1986) identified three different types of anxieties: communication apprehension, fear of negative evaluation and test anxiety. Firstly, communication apprehension is connected to the state in which a learner feels shy, uncomfortable and stressed while talking to others or speaking the target language (Toth, 2010; Marzec-Stawiarska, 2015). This kind of anxiety occurs when learners feel unable to speak, discuss, ask and answer questions in a speaking class; they fail to communicate smoothly and effectively. Secondly, fear of negative evaluation is defined as "apprehension about other's evaluations, distress over their negative evaluations, and the expectation that others would evaluate oneself negatively" (Watson \& Friend, 1969:449). Moreover, fear of negative evaluation is "essentially a cognitive construct and may be particularly amenable to cognitive interventions" (Anderson \& Hope, 2014:681). In an EFL context, it refers to academic evaluation as well as personal evaluations of the learners on the basis of their performance (Toth, 2010). Finally, the last component of foreign language anxiety is test apprehension or test anxiety. Test anxiety is an apprehension over academic evaluation. It is a fear of failing in tests and an unpleasant experience held consciously or unconsciously by learners. It comes from a fear of failure (Horwitz \& Young, 1991). It is the fear of exams, quizzes, and other assignments used to evaluate students' performance ( $\mathrm{Wu}, 2010)$. Moreover, text anxiety is the feeling experienced in the context of both less and more formal examinations There are two major components of test anxiety; the cognitive component "worry", which refers to concerns about being evaluated and about the consequences of failure, and the affective component "emotionality", which refers to the perception of autonomic reactions evoked by the test situation. (Liebert \& Morris,1967). 


\section{Sources of Foreign Language Anxiety}

To reduce the negative influence of foreign language anxiety, it is useful to determine the sources of foreign language anxiety to better understanding of the nature of anxiety, and to help English instructors find suitable and effective strategies to reduce anxiety in language classrooms. Chan \& Wu (2004) mentioned five sources of anxiety among Taiwanese learners: low proficiency, fear of negative evaluation, competition of games, anxious personality, and pressure from students themselves and their parents. They argued that tests, speaking in front of others, spelling, incomprehensible input, and speaking to native speakers were the five anxiety-provoking situations. Previous studies revealed that personal and impersonal anxieties, learners' beliefs about learning a foreign language, teachers' beliefs about teaching a foreign language, classroom procedures, testing, the level of language course, language skills, motivation, proficiency, teachers, tests, and culture are among the main sources of language anxiety (Aydin, 2008; Price, 1991; Young, 1991). Moreover, personality factors, fear of negative evaluation, parental pressure, low English proficiency, lack of preparation, pressure from the language instructor, and tests were the common sources of foreign language anxiety (Jen, 2003). Finally, limited English proficiency, lack of confidence, class management, insufficient class preparation, teaching procedures, fear of negative evaluation, and lack of teaching experience are among the sources of language anxiety (Mahmoodzadeh, 2013).

\section{The impact of FL anxiety on language proficiency}

Many studies have been conducted to investigate the level on foreign language anxiety, and the relationship between foreign language anxiety and language proficiency. Concerning the receptive skills, Serraj \& Noordin (2013) found that the relationship between foreign language anxiety and foreign language listening anxiety of the participants are in accordance with each other. Golchi (2012) found that listening anxiety had negative correlation with listening comprehension and female learners were more anxious than male learners. Moreover, Um, Tubsree \& Surasin (2013) conducted a study on third year EFL students at the Institute of Foreign Languages (IFL), Cambodia on their levels of English reading anxiety. The findings revealed that third year EFL students had a low level of English reading anxiety and reading anxiety had a moderate effect on their reading comprehension. Also, Huang (2012) studied the correlation between foreign language anxiety and English reading anxiety. The findings showed that Chinese students are bothered by reading anxiety, and there was a significant negative relationship between foreign language anxiety and English reading anxiety. The findings of Jafarigohar \& Behrooznia (2012) and Mohd. Zin \& 
Rafik-Galea (2010) also confirmed the significant negative relationship between foreign language anxiety and reading comprehension. Conversely, $\mathrm{Wu}$ (2012) found that there was no significant relationship between anxiety and reading comprehension. In addition, the study of Cabansag (2013) reflected that the respondents' English language classroom anxiety level is moderate and there was insignificant relationship between the language anxiety of the respondents and their reading comprehension performance. As shown above, the previous research had uncertain findings about the relationship between language anxiety and the receptive skills.

Concerning the productive skills, most of the studies revealed moderate to high level of speaking anxiety (Suleimenova, 2012; Yahya, 2013; Liu, 2012; Lian \& Budin, 2014; Muhaisen \& Al-Abed Al-Haq, 2012). It was clear from the previous research that there was a significant negative relationship between language anxiety and speaking (Gkonou, 2011; Chiang, 2012; Liu, 2012). On the other hand, the research conducted on language anxiety and writing skill showed consistent results. Jebreil et al. (2015) and Rezaei \& Jafari (2014) found that EFL Iranian students majoring in English language experienced a high level of anxiety. On the other hand, Aljafen (2013) investigated the writing anxiety of Saudi students and concluded that they have moderate writing level of anxiety. Moreover, Zhang (2011) explored the ESL writing anxiety among Chinese English majors students and found that the freshmen in general had moderate levels of English writing anxiety, while the sophomores had high levels of English writing anxiety. Regarding the relationship between language anxiety and writing skill, the findings of the previous research showed a negative significant relationship between anxiety and writing skill (Naghadeh et al., 2014; Negari \& Rezaabadi, 2012; Zhang, 2011).

\section{The impact of Gender on FL anxiety}

Gender is a significant factor in language learning; it plays a critical role in learning a foreign language. Finding gender-based differences in language anxiety may help instructors to find suitable ways to remove or at least reduce its risky effects. Reviewing the previous research showed that a large amount of research indicated that gender influences the level of foreign language anxiety among learners. It was believed that females are more anxious than female, but this assumption is almost confusing since many studies proved that male students also experience anxiety more than female students, and few studies pointed out no differences in language anxiety due to gender.

With respect to the studies that found female students are more anxious than male students when learning a foreign language, Ucgun (2011) examined the writing anxiety levels of primary school 6, 7 and 8th year 
students in terms of several variables using the "writing anxiety scale" developed by Yaman (2010). The study group was composed of 1407 students enrolled at the 6, 7 and 8th years of 10 primary schools in Sarkisla district of Sivas province. The findings showed that the writing anxiety levels of the students significantly differed according to gender in favor of the female students. Mesri (2012) also conducted a study to investigate the relationship between EFL learners' Foreign Language Classroom Anxiety (FLCA) with regard to gender The results indicated that Iranian female EFL learners had scored higher mean in all anxiety categories than male learners. In Arabian context, Muhaisen \& Al-Abed Al-Haq (2012) investigated the language anxiety experienced by $2^{\text {nd }}$ secondary students in second Amman Directorate of Education. The study showed that there were statistical significant differences between male and female students in their anxiety in learning English while learning reading and writing favored female students. In addition, Golchi (2012) studied listening anxiety among 63 IELTS Iranian learners consisting of 29 males and 34 females. The study revealed a significant difference between male and female learners in their listening anxiety; female learners were more anxious than male learners. Moreover, Arnaiz \& Guillen (2012) investigated the individual differences in the foreign language anxiety (FLA) of 216 participants in a Spanish university context. The analyses indicated that anxiety among female students was higher than among their male counterparts. Considering reading anxiety, Jafarigohar \& Behrooznia (2012) investigated the correlation between the construct of Foreign Language Reading Anxiety (FLRA) and reading comprehension skill among Iranian distance EFL learners with age and gender serving as moderator variables. They concluded that woman participants were significantly more anxious about reading foreign language than men participants. Finally, Naghadeh et al. (2014) investigated the relationship between anxiety and written narrative proficiency. The findings indicated that there was a significant relationship between anxiety and gender and females' anxiety was higher than males' anxiety.

Conversely, Awan et al. (2010) noted that male undergraduates were more anxious than females and this difference was statistically significant. This result showed that female undergraduates were more confident and had greater ability to learn a new language and cope with the feelings of anxiety and nervousness. Moreover, Hussain, Shahid \& Zaman (2011) confirmed the previous findings and found a statistically significant difference between male and female students regarding foreign language classroom anxiety scale in favor of male students. Later, Lian \& Budin (2014) explored the differences between male and female students in language anxiety and found a significant difference between male and female subjects in favor of male students. 
In the meantime, few studies showed that gender was an ineffective factor which might affect anxiety in learning a foreign language. Wu (2012) carried out a study to investigate the relationship between language anxiety (LA) and reading anxiety (RA). The results from two measures of anxiety completed by (91) university students showed that there were no significant differences between males and females in their level of language anxiety. After that, Ghonsooly \& Loghmani (2012) investigated the relationship between EFL learners' foreign language reading anxiety levels and use of reading strategies of 196 senior university EFL learners majoring in either English translation or English literature. The result of independent sample ttest indicated there was no significant difference between males and females in anxiety. Finally, Nahavandi \& Mukundan (2013) conducted a study to understand the level of anxiety of the Iranian EFL students towards English as a foreign language. 548 students (elementary to advanced learners) were selected based on random sampling. The finding showed that gender didn't affect anxiety significantly.

\section{English Language Learning in Higher Education in Saudi Arabia}

The Saudi Arabian higher education system is quite young; about $65 \%$ of the government universities were established in the last 15 years (Alrashidi \& Phan, 2015). In 2014, the number of students enrolling in government universities was 1,307, 481. Exactly 53,606 of them are studying at Taif University (Ministry of Education, 2014) where this study was conducted. To bridge the gap in learning English language between secondary school level and university level, all students have to enroll in a preparation year which is called the "Preparatory Year" before they can specialize in one of the mainstreams. During this year, students take general courses concentrating on skills and take an English compulsory course in which students should attend 12 hours per week for two semesters.

Students, who end this year successfully and want to specialize in English language, should study for four years and pass 119 credit hours (Taif University, 2014). Arabic language is not allowed and only English is the language of instruction. Some professors, who teach in the Foreign Language Department, are native speakers of English and the most are native speakers of Arabic language.

The Saudi high school system primarily utilizes rote methods of instruction and does not expect independent learning from students (AlSaraj, 2014). Most learners often appear reluctant to participate in classroom discourse, are unwilling to provide responses, seldom ask questions, and are unwilling to engage in class discussions (Alrabai, 2014). The transition from this system to higher education requires well equipped classrooms and active students who participate, discuss and learn independently. These 
requirements may affect students' abilities and their motivation to learn English and most of them may experience anxiety which would affect their learning outcomes.

\section{Methodology}

\section{Research Design}

The present study employed a mixed-method approach. Quantitative and qualitative data were collected using questionnaires, records and interviews. The descriptive methodology was employed to investigate the students' anxiety level and anxiety factors of EFL students at the Foreign Language Department at Taif University, Saudi Arabia. The correlational methodology was also used to determine the relationship between students' language anxiety and their language proficiency.

\section{Participants}

The population of the study was all male and female students $(n=$ 1350) enrolled in the Foreign Language Department at Taif University in first semester of the academic year 2015/2016. The participants were majoring in English language. A stratified sampling was used to select male and female students, and to select equivalent number of different academic levels. Table (1) shows that the study sample comprised (373) students; 55\% $(n=205)$ male and 45\% $(n=168)$ female. The study sample consisted of $21.2 \%(n=79)$ freshmen, 23\% $(n=86)$ sophomore, $29.8 \%(n=111)$ junior and $26 \%$ (n=97) senior.

Table (1): Number of participants according to gender and academic level

\begin{tabular}{lllllllllll}
\hline & \multicolumn{2}{l}{ Freshman } & \multicolumn{2}{l}{ Sophomore } & \multicolumn{2}{l}{ Junior } & \multicolumn{3}{c}{ Senior } & \multicolumn{2}{c}{ Total } \\
\hline & $\mathrm{N}$ & $\%$ & $\mathrm{~N}$ & $\%$ & $\mathrm{~N}$ & $\%$ & $\mathrm{~N}$ & $\%$ & $\mathrm{~N}$ & $\%$ \\
\hline Male & 37 & 9.9 & 40 & 10.7 & 61 & 16.4 & 67 & 18 & 205 & 55 \\
\hline Female & 42 & 11.3 & 46 & 12.3 & 50 & 13.4 & 30 & 8 & 168 & 45 \\
\hline Total & 79 & 21.2 & 86 & 23 & 111 & 29.8 & 97 & 26 & 373 & 100 \\
\hline
\end{tabular}

For deeper investigation of students' foreign language anxiety, 30 high-anxious participants (15 male and 15 female) were chosen according to their scores in (FLCAS) questionnaire to be interviewed.

\section{Instruments}

To achieve the purpose of this study, the following instruments were utilized: A modified version of FLCAS, Inventory of Foreign Language Anxiety Factors (IFLAF) designed by the researcher, students' academic records and semi-structured interviews. 


\section{The Foreign Language Classroom Anxiety Scale (FLCAS):}

A modified version of FLCAS was used in this study. The original version of FLCAS is a 33-item, 5-point Likert-scale instrument ranged from (strongly disagree to strongly agree) measuring students language anxiety (Horwitz et al., 1986). The modified version was translated into Arabic, then translated into English to check its consistency. It contained only 24 items; Nine items from the original FLCAS were eliminated due to lack of consistency with the research purpose or related to interaction with native speakers since most of the students do not have opportunity to communicate with native speakers of English language. During data coding, the scores of items $(2,5,8,17,20)$ were reversed. The scale possible score ranges from 24120 . The validity of the scale was tested. It was distributed to a number of specialists in instruction and measurement. The reliability of the scale was calculated using Cronbach's Alpha; it was $(0.91, n=60)$ suggesting that the scale is reliable.

\section{Inventory of Foreign Language Anxiety Factors (IFLAF):}

The research related to foreign language anxiety was revised to build an instrument that measures the factors that may cause foreign language anxiety. A number of studies have mentioned different factors related to language anxiety (Young, 1991; Williams \& Andrade, 2008; Al-shalawi, 2010; Zhang, 2011; Rezaei \& Jafarib, 2014; Kamaruddin\& Abdullah, 2015). IFLAF is an 18-item, 5-point Likert instrument ranged from strongly disagree (1 point) to strongly agree (5 points). The validity was verified through distributing the scale to a number of specialists in instruction and measurement. The reliability of the scale was calculated using Cronbach's Alpha; it was $(0.87, \mathrm{n}=60)$ suggesting that the scale is reliable.

\section{Students' Academic Records:}

The grades of the English language proficiency (grammar, speaking, writing and reading and GPA) for the participants were collected from the students' academic records. The maximum grade for each skill is 100 points.

\section{A Semi-structured interview:}

A semi-structured interview was designed to gather information needed for deeper understanding of the factors affecting foreign language anxiety.

\section{Data Collection Procedure and Analysis}

To assess students' EFL anxiety level and factors affecting their language anxiety, arithmetic means and standard deviations of each item of (FLCAS) and (IFLAF) were calculated. The criteria used to determine 
students' language anxiety level and the degree of the factors affecting their language anxiety was as follow: From (1 to less than 1.8$)$ very low, (1.8 to less than 2.6) low, (2.6 to less than 3.4) moderate, (3.4 to less than 4.2) high, and (4.2 to 5) very high. To determine whether there were any significant correlation between students' language anxiety level and language proficiency (grammar, speaking, writing, reading and GPA), Pearson correlation Coefficient for each pair of variables were calculated. In addition, Independent samples T-test was used to explore any statistically significant differences between the students' responses related to gender. One-way ANOVA was used to determine any statistically significant differences between students' foreign language anxiety level related to their academic level. Finally, the semi-structured interview tool was used to gather qualitative data needed for deeper understanding of foreign language anxiety.

\section{Results and Discussion}

To determine the level of foreign language anxiety of Saudi EFL students, the modified version of FLCAS was translated into Arabic to make sure that all students understand the items easily and administered to the study sample. The mean scores and standard deviations were calculated, and the items of the FLCAS were arranged in descending. The results are illustrated in Table (2) below:

\begin{tabular}{|c|c|c|c|c|}
\hline Item No. & Item & Mean & SD & Level \\
\hline 10 & $\begin{array}{l}\text { I worry about consequences of failing my English } 373 \\
\text { language class. }\end{array}$ & 3.52 & 1.40 & high \\
\hline 11 & $\begin{array}{l}\text { In English language class, I can get so nervous I } 373 \\
\text { forget things I know. }\end{array}$ & 3.43 & 1.11 & high \\
\hline 8 & $\begin{array}{l}\text { I am usually at ease during tests in my English } 373 \\
\text { language class.(R) }\end{array}$ & 3.41 & 1.05 & high \\
\hline 9 & $\begin{array}{l}\text { I start to panic when I have to speak without } 373 \\
\text { preparation in English language class. }\end{array}$ & 3.32 & 1.10 & moderate \\
\hline 22 & $\begin{array}{l}\text { I feel overwhelmed by the number of rules you } 373 \\
\text { have to learn to speak English language. }\end{array}$ & 3.20 & 1.18 & moderate \\
\hline 21 & $\begin{array}{l}\text { I get nervous when I don’t understand every word } 373 \\
\text { the English language teacher says. }\end{array}$ & 3.18 & 1.15 & moderate \\
\hline 13 & $\begin{array}{l}\text { I get upset when I don't understand what the } 373 \\
\text { teacher is correcting. }\end{array}$ & 3.18 & 1.18 & moderate \\
\hline 24 & $\begin{array}{l}\text { I get nervous when the English language teacher } \\
\text { asks questions which I haven't prepared in } 373 \\
\text { advance. }\end{array}$ & 3.13 & 1.13 & moderate \\
\hline 4 & $\begin{array}{l}\text { It frightens me when I don't understand what the } \\
\text { teacher is saying in the English language class. }\end{array}$ & 3.08 & 1.28 & moderate \\
\hline 18 & $\begin{array}{l}\text { I always feel that the other students speak English } 373 \\
\text { language better than I do. }\end{array}$ & 2.96 & 1.18 & moderate \\
\hline
\end{tabular}




\begin{tabular}{|c|c|c|c|c|}
\hline 2 & $\begin{array}{l}\text { I don't worry about making mistakes in English } 373 \\
\text { language class. (R) }\end{array}$ & 2.92 & 1.01 & moderate \\
\hline 3 & $\begin{array}{l}\text { I tremble when I know that I'm going to be called } 373 \\
\text { on in English language class. }\end{array}$ & 2.83 & 1.07 & moderate \\
\hline 7 & $\begin{array}{l}\text { I keep thinking that the other students are better at } 373 \\
\text { English language than I am. }\end{array}$ & 2.83 & 1.10 & moderate \\
\hline 1 & $\begin{array}{l}\text { I never feel quite sure of myself when I am } 373 \\
\text { speaking English in my foreign language class. }\end{array}$ & 2.82 & .94 & moderate \\
\hline 5 & $\begin{array}{l}\text { It wouldn't bother me at all to take more English } 373 \\
\text { language classes. (R) }\end{array}$ & 2.81 & 1.15 & moderate \\
\hline 16 & $\begin{array}{l}\text { The more I study for an English language test, the } 373 \\
\text { more confused I get. }\end{array}$ & 2.81 & 1.15 & moderate \\
\hline 14 & $\begin{array}{l}\text { Even if I am well prepared for English language } 373 \\
\text { class, I feel anxious about it. }\end{array}$ & 2.68 & 1.15 & moderate \\
\hline 20 & $\begin{array}{l}\text { When I am on my way to English language class, I } 373 \\
\text { feel very sure and relaxed. (R) }\end{array}$ & 2.67 & 1.01 & moderate \\
\hline 17 & $\begin{array}{l}\text { I don't feel pressure to prepare very well for } 373 \\
\text { English language class. (R) }\end{array}$ & 2.63 & 1.07 & moderate \\
\hline 12 & $\begin{array}{l}\text { It embarrasses me to volunteer answers in my } 373 \\
\text { English language class. }\end{array}$ & 2.63 & 1.06 & moderate \\
\hline 15 & $\begin{array}{l}\text { I am afraid that my English language teacher is } 373 \\
\text { ready to correct every mistake I make. }\end{array}$ & 2.63 & 1.07 & moderate \\
\hline 6 & $\begin{array}{l}\text { During language class, I find myself thinking } \\
\text { about things that have nothing to do with the } 373 \\
\text { course. }\end{array}$ & 2.60 & 1.16 & moderate \\
\hline 19 & $\begin{array}{l}\text { I feel very self-conscious about speaking English } 373 \\
\text { language in front of other students. }\end{array}$ & 2.53 & 1.16 & low \\
\hline 23 & $\begin{array}{l}\text { I am afraid that the other students will laugh at me } 373 \\
\text { when I speak English language. }\end{array}$ & 2.44 & 1.28 & low \\
\hline Overall & 373 & 2.93 & 0.61 & moderate \\
\hline
\end{tabular}

Table (2): Descriptive Analysis of the participants' responses to FLCAS $\mathrm{R}=$ Reversed Items.

The table above showed that the level of Saudi students' foreign language anxiety was moderate $(\mathrm{M}=2.93)$. Items $(10,11 \& 8)$ got the highest mean scores; $(\mathrm{M}=3.52),(\mathrm{M}=3.43)$ and $(\mathrm{M}=3.41)$ respectively. The highest score was calculated for item (10), "I worry about consequences of failing my English language class". This suggests that students mostly worry about failing their English classes because exams make them more anxious and nervous. This finding is consistent with Cabansag (2013) who investigated the relationship between language and reading anxiety and reading comprehension performance of $\mathrm{AB}$ English students and found that fearing of failing classes was high $(\mathrm{M}=3.68)$. It contradicts the findings of Javid (2014) and Alrabai (2014) which indicated that worrying the consequences of failing foreign language classes of Saudi EFL learners' were low $(M=2.31)$ and moderate $(M=3.07)$ respectively; this contradiction may be 
due to the different samples of these two studies. Item (11), "In English language class, I can get so nervous that I forget things I know.", gained the second highest mean score $(M=3.43)$. This findings indicates that most teachers give priority to remembering and memorization, so students get nervous of forgetting the information they already know. This goes in line with Javid (2014) and Alrabai (2014) who found that Saudi students were highly anxious in this concern, $(M=3.65)$ for both studies. This finding is partially different from Cabansag's (2013) finding which was moderate $(\mathrm{M}=3.17)$. The third highest item was "I am usually at ease during tests in my English language class", $(M=3.41)$. This item is reversed so students had high anxiety during English language tests; this may be referred to the nature of exams administered to students. It is clear that examinations concentrate on the lower levels of knowledge, so students face difficulties in mere memorization. This result is partially similar to Javid (2014), Alrabai (2014) and Cabansag (2013) who claimed that students faced moderate anxiety during language exams, $(M=3.09),(M=3.33)$ and $(M=2.83)$ respectively. Two items $(19,23)$ had low levels of anxiety $(M=2.53$ and $M=2.44)$ respectively. Both of these items are related to speaking anxiety. They may gain low average because listening is taught in large groups, and instructors do not have the chance to involve all students in listening and speaking activities. Besides, due to the lack of language laboratories, listening and speaking are taught in the same way other skills taught, and what supports this claim is students' high gain in speaking (79\%) which is the highest grade of the students' language skills. These findings contradict those of Javid (2014), Alrabai (2014) and Cabansag (2013) which indicated that students had moderate anxiety ranged from $(M=2.66)$ to $(M=299)$. The conflicts of these findings may be due to the fact that the participants of the current study are English majoring students, while the mentioned above studies' participants took English language as general courses.

In general, the current study finding ascertains that Saudi EFL students at the English department in Taif University had moderate foreign language anxiety. 22 items of 24 were high or moderate; ranging from $(M=2.60$ to $M=3.52)$. Speaking a language without preparation is a source of anxiety due to students' lack of self-confidence when speaking, so teachers have to encourage students when speaking and never pick up every mistake. Similarly, the number of grammatical rules needed to speak the language increases students' anxiety since English language rules are completely different from Arabic language rules and students make many mistakes due to the two languages interference. Vocabulary is considered an important source of anxiety. Insufficient number of vocabulary affects students' ability to speak or write so they get upset and their language anxiety increases. Teachers have to teach vocabulary in use and speak in a normal pace to 
enable students understand and acquire the pronunciation and meanings of vocabulary. These findings are consistent with the previous studies (AlAsmari, 2015; Kamaruddin \& Abdullah, 2015; Javid, 2014; Lian \&Budin, 2014; Arnaiz \& Guillen, 2012; Shabani, 2012) which were conducted in the field of foreign language anxiety.

Concerning the factors that cause students' foreign language anxiety, mean scores, standard deviations and level of each item were calculated in Table (3).

Table (3): Descriptive Analysis of the participants' responses to IFLAF

\begin{tabular}{|c|c|c|c|c|c|}
\hline Item No. & Item & $\mathrm{N}$ & Mean & SD & Level \\
\hline 15 & Instructor's personality and behavior. & 373 & 3.58 & 1.13 & high \\
\hline 16 & $\begin{array}{c}\text { Methods of teaching and pedagogical } \\
\text { practices. }\end{array}$ & 373 & 3.40 & 1.09 & high \\
\hline 4 & $\begin{array}{l}\text { Difficulty of remembering } \\
\text { appropriate vocabulary. }\end{array}$ & 373 & 3.37 & 1.08 & moderate \\
\hline 2 & $\begin{array}{l}\text { Worrying about pronunciation } \\
\text { mistakes. }\end{array}$ & 373 & 3.24 & 1.05 & moderate \\
\hline 3 & $\begin{array}{l}\text { Worrying about grammatical } \\
\text { mistakes. }\end{array}$ & 373 & 3.17 & .98 & moderate \\
\hline 7 & $\begin{array}{l}\text { Difficulty of understanding long } \\
\text { written sentences. }\end{array}$ & 373 & 3.16 & 1.06 & moderate \\
\hline 13 & Fear of making mistakes. & 373 & 3.09 & 1.18 & moderate \\
\hline 9 & $\begin{array}{c}\text { Having no idea or opinion about the } \\
\text { topic. }\end{array}$ & 373 & 3.02 & 1.02 & moderate \\
\hline 5 & Reading Comprehension difficulty. & 373 & 3.00 & 1.04 & moderate \\
\hline 14 & $\begin{array}{l}\text { Difficulty of understanding teacher's } \\
\text { question or comment. }\end{array}$ & 373 & 2.98 & 1.04 & moderate \\
\hline 6 & $\begin{array}{c}\text { Difficulty of understanding spoken } \\
\text { English. }\end{array}$ & 373 & 2.94 & 1.03 & moderate \\
\hline 1 & Speaking in front of others. & 373 & 2.93 & 1.49 & moderate \\
\hline 11 & $\begin{array}{l}\text { Worrying about one's ability level } \\
\text { compared to others. }\end{array}$ & 373 & 2.92 & 1.09 & moderate \\
\hline 8 & Insufficient writing techniques. & 373 & 2.80 & 1.07 & moderate \\
\hline 12 & $\begin{array}{l}\text { Fear of negative reaction from others, } \\
\text { teacher and peers. }\end{array}$ & 373 & 2.78 & 1.13 & moderate \\
\hline 17 & Low self-confidence. & 373 & 2.68 & 1.13 & moderate \\
\hline 18 & $\begin{array}{l}\text { Negative beliefs about language } \\
\text { learning. }\end{array}$ & 373 & 2.66 & 1.21 & moderate \\
\hline 10 & $\begin{array}{c}\text { Difficulty of understanding other } \\
\text { students. }\end{array}$ & 373 & 2.53 & .97 & low \\
\hline & Overall & 373 & 3.01 & .61 & moderate \\
\hline
\end{tabular}


Table (3) details the descriptive analyses of students' responses to the Inventory of Foreign Language Anxiety Factors (IFLAF). The overall mean score of these factors is moderate $(\mathrm{M}=3.01)$. Almost all 20 items are considered as anxiety factors. The mean scores of these factors range from $(\mathrm{M}=2.53$ to $\mathrm{M}=3.58)$. The highest anxiety-provoking factors included items (15 and 16). Item (15); "Instructor's personality and behavior." got the highest mean score $(M=3.58)$. This factor is extrinsic and related to language teachers' behaviors and manners in the classroom. The second highest factor was "Methods of teaching and pedagogical practices" $(M=3.40)$, which means that instructors use old-fashion teaching methods that do not fulfill students' needs. Also, the pedagogical practices are part of the problem of anxiety; since these practices are not taking the advantage of the new technologies and methods that emerged in the $21^{\text {st }}$ century. These findings are in accordance with the findings of the study of Kamaruddin \& Abdullah (2015) which revealed that instructor-students' interaction was considered the main factor contributing to anxiety. Other factors that cause foreign language anxiety are "Difficulty of remembering appropriate vocabulary, (M=3.37), "Worrying about pronunciation mistakes, $(M=3.24)$, "Worrying about grammatical mistakes, $(\mathrm{M}=3.17)$, and "Difficulty of understanding long written sentences, $(\mathrm{M}=3.16)$. These findings are in line with Awan et. Al (2010) who examined the anxiety of 149 undergraduates in English undergraduate classes and found that "Worries about pronunciation", (55\%) and "worries about grammatical mistakes", (47\%) were of the major causes of anxiety.

To decrease the impact of foreign language anxiety on students, a proposed model is introduced (figure:1):

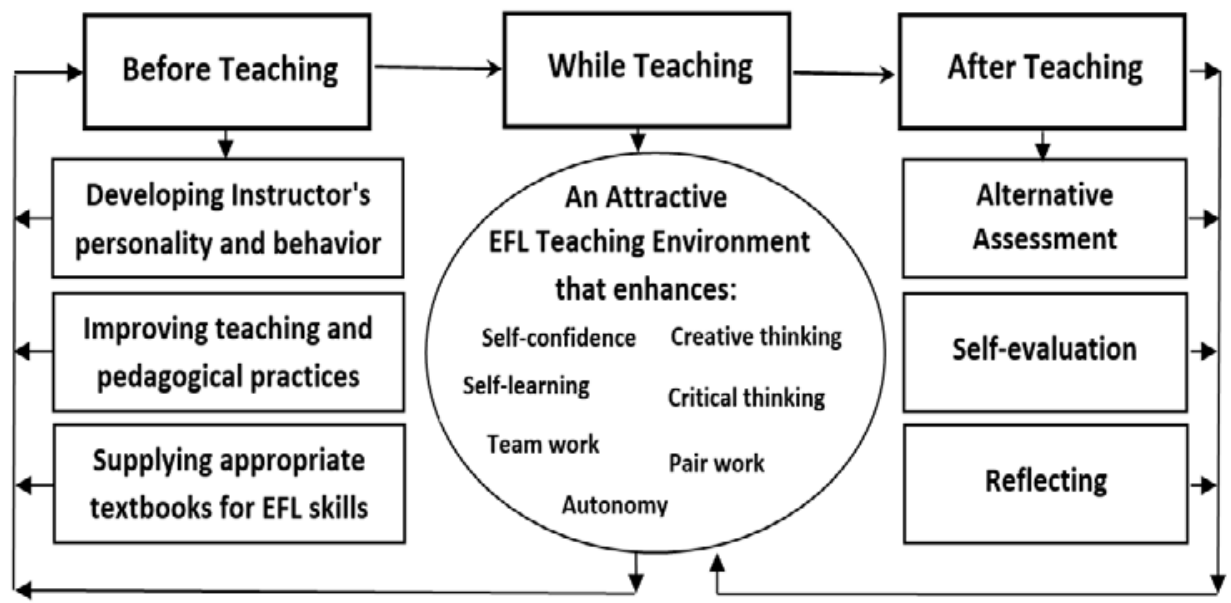

Figure (1): A Proposed Model for Reducing FLA in Higher Education 
The above figure illustrates the procedures that instructors can apply inside classrooms to decrease the negative consequences of foreign language anxiety. The first component deals with before-teaching phase. It focuses on the highest factors that affect students' foreign anxiety that achieved by the current study. Before teaching, instructors are obliged to direct their behaviors, because some negative behaviors cause fear and tension, so students will be affected and feel uneasiness when learning a language. Moreover, teaching and pedagogical practices carried out by language instructors are old-fashioned. They do not pursue the new approaches and techniques of the new era. So, instructors have to challenge themselves and improve their practices to cope the teaching situations inside classroom. Finally, the textbooks assigned in learning the language should be developed and modified, since they are mostly the main source of knowledge. They should be new, attractive and should focus on students' needs.

The second component of the Model deals with the practices done while teaching. Creating an attractive EFL teaching environment is crucial. This environment supposed to enhance students' learning through applying new and effective learning strategies. Most of the current practices are teacher-centered. They ignore the characteristics and needs of students. Learners should be given more roles and tasks to be responsible and should bear their learning responsibilities. Learning inside classes should be shifted from traditional practices to student-centered learning. Students should be helped to increase their self-confidence and autonomy. They have to be enrolled in pair and team work to depend on their selves and learn meaningful knowledge. Critical and creative thinking should be encouraged and practiced instead of mere memorization and remembering.

The third component of the Model focuses on a very important factor that cause anxiety which is evaluation represented by quizzes and examinations. Most of language instructors, as students claim, use traditional evaluative methods. This causes fear of exams and uneasiness during midterm or final exams because students are not certain of the content of the course and the way the exams will be presented. Instructors have to consider alternative assessment as a useful solution for exams problems. They have to train students on exams and encourage them to reflect on their performance in exams to make evaluation a way of learning. Besides, instructors have to adapt and build evaluation tools that are valid and reliable. Finally, they must take in consideration their students' result to strength the useful outcomes and treat the defects.

To test if there any statistically significant relationship between students' foreign language anxiety level and the language proficiency, Pearson Correlation Coefficient was employed for (Grammar, speaking, writing, reading and GPA). 
Table (4): Results of Pearson Correlation Coefficient between anxiety and language proficiency

\begin{tabular}{ccccccc}
\hline & & Grammar & Speaking & Writing & Reading & GPA \\
\hline \multirow{2}{*}{ Anxiety } & $\begin{array}{c}\text { Pearson } \\
\text { Correlation }\end{array}$ & $-.247^{* *}$ & $-.349^{* *}$ & $-.243^{* *}$ & $-.273^{* *}$ & $-.281^{* *}$ \\
\cline { 2 - 7 } & Sig. & .000 & .000 & .000 & .000 & .000 \\
\hline
\end{tabular}

** Correlation is significant at the 0.01 level.

The analyses of the correlation coefficients between anxiety and the language proficiency revealed that foreign language anxiety had moderately significant and negative relationship to all of the language proficiency (Grammar, speaking, writing, reading and GPA). The value of the coefficients ranged from ( $\mathrm{r}=-.243)$ for anxiety and writing to $(\mathrm{r}=-.349)$ for anxiety and speaking. The highest relationship was found between anxiety and speaking ( $\mathrm{r}=-.349)$ which confirms that speaking is a cause of fear among students. This finding is consistent with Gkonou (2011) who found a significant negative correlation between classroom anxiety and speaking indicating that the English language classroom context was a source of speaking anxiety. It also confirms the findings of Liu (2012) which indicated that the relationship between anxiety and listening was highly significant and negative. Surprisingly, the findings contradict the study of Lian \& Budin (2014) which revealed a positive correlation between the subjects' language anxiety and oral English test achievement $(\mathrm{r}=.360), \mathrm{p}<0.01$. The second highest relationship was between anxiety and reading $(\mathrm{r}=-2.73)$ which indicates that reading is an important source of anxiety since students are required to read in front of their classmate and answer comprehension questions that may be ambiguous or unfamiliar to them. This finding is in accordance with Liu (2012) who found a negative significant relationship between anxiety and reading among 150 EFL freshmen from a university in central Taiwan. It also goes in line with Tsai \& Li (2012) who investigated the relationships between anxiety and English reading proficiency of 302 EFL Taiwanese college freshmen enrolled in Freshman English and found that English reading proficiency was negatively related to foreign language reading. Grammar was also negatively significant related to anxiety $(\mathrm{r}=-$ .247), and this finding is in accordance with Nahavandi \& Mukundan (2013) who investigated the relationship between language anxiety and the four skills of 548 students (elementary to advanced learners) studying in JahadeDaneshgahi institute of Tabriz, Iran. The relationship between language anxiety and writing had the lowest value among the four skills but was also negatively significant ( $\mathrm{r}=-.243)$. It confirms the findings of Naghadeh et.al (2014) which revealed that a negative significant relationship between anxiety and written narrative proficiency among 62 Iranian students from 
three institutes in Naghade. From the above findings, it is clear that the relationship between foreign language anxiety and speaking and reading is higher than grammar and writing because speaking and reading skills require students' oral participation and pronunciation, but grammar and writing skills can be learned and studied without being involved in direct participation. Finally, the finding showed a negative significant relationship between foreign language anxiety and achievement represented by the GAP ( $\mathrm{r}=-.281)$. These finding are consistent with Awan et. Al (2010) and Arnaiz \&Guillen (2012) which revealed a negative relationship between anxiety and academic achievement.

Table (5): Differences between male and female students in FLCAS and IFLAF

\begin{tabular}{|c|c|c|c|c|c|c|}
\hline & GENDER & $\mathrm{N}$ & Mean & $\mathrm{t}$ & df & Sig. \\
\hline \multirow{2}{*}{$\begin{array}{l}\text { Anxiety } \\
\text { FLCAS }\end{array}$} & Male & 205 & 2.91 & \multirow{2}{*}{$-.484-$} & \multirow{2}{*}{371} & \multirow{2}{*}{0.63} \\
\hline & Female & 168 & 2.94 & & & \\
\hline \multirow{2}{*}{$\begin{array}{c}\text { Factors } \\
\text { affecting Anxiety } \\
\text { IFLAF }\end{array}$} & Male & 205 & 3.04 & \multirow[b]{2}{*}{0.987} & \multirow[b]{2}{*}{371} & \multirow{2}{*}{0.32} \\
\hline & Female & 168 & 2.98 & & & \\
\hline
\end{tabular}

Table 2 makes it clear that female students are more anxious than males, but this difference is not statistically significant $(t=-.484), p=.63)$. Similarly, the differences between male and female students regarding the factors affecting anxiety as measured by (IFLAF) are not statistically significant $(\mathrm{t}=.987, \mathrm{p}=.32)$ although males are higher in this domain. The findings are in line with Nahavandi \&Mukundan (2013), and with Wu (2012) who investigated the anxiety and reading comprehension performance in English as a language among 91 Taiwanese university students and found that language anxiety did not differ significantly across gender. It also confirms the findings of Shabani (2012) who investigated the levels and sources of language anxiety and fear of negative evaluation among 61 Iranian EFL Learners(22males, 39females) studying English literature at Ilam University and found that there was no significant difference between males and females in the levels of anxiety. Conversely, the findings contradict that of Mesri (2012) which indicated that Iranian female EFL learners had scored higher mean in all anxiety categories than male learners', and Arnaiz \&Guillen (2012) which investigated the individual differences in the foreign language anxiety(FLA) of 216 participants in a Spanish university context and revealed that females experienced more anxiety than males. Moreover, Lian \& Budin (2014) findings revealed that there was significant difference between Malaysian male and female subjects; boys were more anxious than girls in English class. The study of Awan et. al (2010) also conflicts with the current study which revealed that male students were more anxious than females and test $(t=2.520, p=.013)$ was 
statistically significant. The current study revealed no statistically significant difference between male and female participants due to the fact that in the Saudi context, female students and male students study in separated classrooms. The conflict of the above findings needs further investigation in this domain.

Table (6): ANOVA results of the differences related to the academic levels in FLCAS

\begin{tabular}{|c|c|c|c|c|c|c|}
\hline & & Sum of Squares & $\mathrm{df}$ & Mean Square & $\mathrm{F}$ & Sig. \\
\hline \multirow{3}{*}{ Anxiety } & $\begin{array}{c}\text { Between } \\
\text { Groups }\end{array}$ & .209 & 3 & .070 & \multirow{3}{*}{.183} & \multirow{3}{*}{.908} \\
\hline & Within Groups & 140.547 & 369 & .381 & & \\
\hline & Total & 140.756 & 372 & & & \\
\hline \multirow{3}{*}{$\begin{array}{c}\text { Factors } \\
\text { affecting } \\
\text { Anxiety }\end{array}$} & $\begin{array}{c}\text { Between } \\
\text { Groups }\end{array}$ & .294 & 3 & .098 & \multirow{3}{*}{.255} & \multirow{3}{*}{.858} \\
\hline & Within Groups & 142.074 & 369 & .385 & & \\
\hline & Total & 142.368 & 372 & & & \\
\hline
\end{tabular}

To examine whether there were any statistically significant differences between students' foreign language anxiety and factors affecting their anxiety related to the academic level, the ANOVA results Table 6 showed that there were no statistically significant differences due to the academic level for students' foreign language anxiety and factors affecting their anxiety $(\mathrm{F}=.183$ and $\mathrm{F}=.255)$ respectively.

These findings concur with that of Awan et. al (2010) which revealed that students in the sixth semester were more anxious than those in the second semester, but this difference $(t=-1.019, p=.310)$ was statistically nonsignificant. They are also in accordance with Yang (2012) who examined the underlying constructs of English classroom anxiety and English communication anxiety, and the relationships between language anxiety and selected individual difference variables among 117 Taiwanese graduate students enrolled in a large southwestern university in the U.S. These findings imply that students at all the academic levels suffer from an equal amount of foreign language anxiety.

In the next section, the qualitative findings are presented and discussed in Table 7. Thirty highly anxious participants (15 male and 15 female) were interviewed using the semi-structured interview. 
Table (7): Qualitative results of the interviews of the causes of LA

\begin{tabular}{|c|c|c|c|c|c|}
\hline No. & Factors Causing Anxiety & $\begin{array}{c}\text { Male } \\
\text { Frequency }\end{array}$ & $\begin{array}{c}\text { Female } \\
\text { Frequency }\end{array}$ & Total & Percentage \\
\hline 1 & $\begin{array}{l}\text { Unsuitability of } \\
\text { syllabuses and textbooks }\end{array}$ & 3 & 7 & 10 & $17.2 \%$ \\
\hline 2 & $\begin{array}{l}\text { Instructor's qualifications } \\
\text { and behavior }\end{array}$ & 5 & 4 & 9 & $15.5 \%$ \\
\hline 3 & $\begin{array}{l}\text { Instructor's way of } \\
\text { teaching }\end{array}$ & 4 & 4 & 8 & $13.8 \%$ \\
\hline 4 & The learning environment & 4 & 3 & 7 & $12.1 \%$ \\
\hline 5 & $\begin{array}{c}\text { Lack of practicing the } \\
\text { language }\end{array}$ & 4 & 3 & 7 & $12.1 \%$ \\
\hline 6 & $\begin{array}{l}\text { Lack of instructor's } \\
\text { support and motivation }\end{array}$ & 3 & 4 & 7 & $12.1 \%$ \\
\hline 7 & $\begin{array}{l}\text { Study Pressure and } \\
\text { Assignments }\end{array}$ & 1 & 3 & 4 & $6.9 \%$ \\
\hline 8 & Literary courses & 2 & 2 & 4 & $6.9 \%$ \\
\hline 9 & Worrying about GPA & 1 & 1 & 2 & $3.4 \%$ \\
\hline & TOTAL & 27 & 31 & 58 & $100 \%$ \\
\hline
\end{tabular}

Table 7 summarizes the most important causes of foreign language anxiety stated by male and female students in the interviews of the highly anxious students. "Unsuitability of syllabuses and textbooks" had the highest percentage (17.2\%) indicating that English language syllabuses and textbooks assigned must be revised and developed to fulfill students' needs and to be realistic and within the students' academic level. The second highest cause was "Instructor's qualifications and behavior" (15.5\%), which prevents students from expressing their ideas well and makes them anxious during class time. Instructor's qualification plays a crucial role in learning the language since he/she is the main source of knowledge and unqualified instructors cannot perform their roles in preparation, teaching, classroom management and evaluation of students' outcomes. The third highest cause was "Instructor's way of teaching" (13.8\%); since even some qualified instructors have difficulties in teaching. They lack the ability to plan the lesson, analyze the learning outcomes, use effective teaching strategies and techniques that suit and gap the students' individual differences. In-service training courses must be designed and implemented to develop instructors' professional practices. Fourth, fifth and sixth causes of anxiety were "The learning environment", "Lack of practicing the language" and "Lack of instructor's support and motivation" which got (12.1\%) for each one. The learning environment is a source of anxiety since most of classrooms are not equipped with necessary devices such as data show, projectors, screens and audios. Besides, there are not adequate opportunities to practice the language inside the classroom due to the large number of students in class, or to the nature of teaching and learning practices employed inside classrooms. Also, 
students have rare opportunities to practice the language outside the classroom due to students' shyness or because of the characteristics of the Saudi society. In addition, some instructors fail to offer the needed support and motivation to students. "Study Pressure and Assignments" and "Literary courses" are seen also sources of foreign language anxiety; (6.9\%) for each one. This pressure is the result of fear arises from the responsibilities and assignments which students have to do without knowing the way that should be followed to attain these duties. Literary courses, as students mentioned, have some negative aspects on students anxiety because students feel that they are very difficult and do not help them acquire the language. Finally, the least factor was "Worrying about GPA", (3.4\%), it is not seen a crucial factor of anxiety for almost all students since the study revealed that the average of students' GPA was (2.47) out of (4).

\section{Conclusion}

The results of this study revealed that Saudi English-majoring students had moderate level of anxiety. The highest provoking causes of students' anxiety were worrying about consequences of failing, forgetting things they know and feeling uneasiness during language tests. The study also revealed that instructor's personality and behavior, methods of teaching and pedagogical practices were sources of classroom anxiety as well. Besides, the participants expressed their anxious feelings of remembering appropriate vocabulary and worries about pronunciation, grammatical mistakes and understanding long written sentences. Moreover, English language syllabuses and textbooks bothered students in the process of learning the language. The analyses of the variables related to foreign language anxiety revealed a significant negative correlation between language anxiety and language proficiency (grammar, speaking, writing, reading and GPA). Gender did not have a significant impact on foreign language anxiety in the current study. Finally, the academic level of students did not affect the level of anxiety indicating that all students, despite their academic level, suffer from the same degree of anxiety.

Based on the findings, an EFL Model (Figure1) was proposed. This model recommends practical procedures before teaching, while teaching and after teaching. The model deals with the factors that cause anxiety and offers solutions to get rid of their effects. It is suggested that the EFL Model proposed in this study applied in classrooms to examine its effect on students' foreign language anxiety. Other suggestions and implications can be derived from the finding to help EFL students overcome foreign language anxiety in classrooms. First, instructors have to create a friendly atmosphere inside classrooms. They have to avoid negative behaviors and manners that enhance anxiety. They have to develop themselves in applying suitable 
teaching methodologies and techniques that foster students' self-learning. These methodologies should adhere to student-centered approaches, and should take the advantages of the new technologies which can promote teaching and learning processes. Second, administrators and curriculum developers within English language departments must take their responsibilities in affording well-designed and modern syllabuses and textbooks that fulfill students' needs. Third, exams should facilitate learning instead of being sources of anxiety. Authentic evaluation should be taken into consideration since it assess the levels of the required skills accurately, and it enhances the validity and reliability of exams. Fourth, there is a big demand for creating an effective learning environment that enables students learn and practice the language in real-life situations. Finally, since there was a significant negative relationship between anxiety and language proficiency (grammar, speaking, reading, writing and GPA), it is very important to encourage students and assist them to avoid foreign language anxiety, because higher levels of anxiety affect students' language proficiency negatively.

The findings of this study are limited to the English major students studying at the Foreign Language Department in Taif University. So, this study can be replicated at many English language departments at other Saudi universities for generalization of the findings in the Saudi context. Further, some studies are recommended based on the findings of the current study. The teaching methods and practices inside classrooms should be investigated to arrive at the highly-rated sources of anxiety. There may be crucial variables that contribute to foreign language anxiety such as teachers' manners, evaluation procedures and the surrounded environment. So, these variables should be addressed deeply for better understanding of anxiety. Although Al-Saraj (2014) developed a scale for measuring anxiety of Arab students, there is a need for developing more scales that deal with all language skills anxiety and verifying their validity and reliability on a large number of male and female students.,

\section{References:}

Alrabai, F. (2014). A Model of Foreign Language Anxiety in the Saudi EFL Context. English Language Teaching, 7(7), 82-101.

AlAsmari, A. (2015). A Comparative Analysis of Preparatory Year Students' FL Anxiety. International Journal of English Linguistics, 5(4), 50-62.

Aljafen, B. (2013). Writing Anxiety Among EFL Saudi Students in Science Colleges and Departments at A Saudi University. Master Thesis, The School of Graduate Studies and Research. 
Alrashidi, O. \& Phan, H. (2015). Education Context and English Teaching and Learning in the Kingdom of Saudi Arabia: An Overview. English Language Teaching, 8(5), 33-44.

Al-Saraj, T. (2014). Revisiting the Foreign Language Classroom Anxiety Scale (FLCAS): The Anxiety of Female English Language Learners in Saudi Arabia. L2 Journal, 6, 50-76.

Alshahrani, M. \& Alandal, A. (2015). An Investigation of Anxiety Among Elementary School Students Towards Foreign Language Learning. Studies in Literature and Language, 11(1), 29-40.

Al-shalawi, H. (2010). Saudi University Male Students' Perceptions and Experience of English Learning Classroom Anxiety. Immam University Journal, 13, 2-34.

Anderson, K. \& Hope, D. (2014). Treatment of Adult Social Anxiety Disorder: A Treatments-by-Dimensions Review. In S. Hofmann \& $\mathrm{P}$. DiBartolo (Eds.), Social Anxiety: Clinical, Developmental, and Social Perspectives (pp.668-703). Third Edition. London: Elsevier.

Arnaiz, P. \&Guillen, F. (2012). Foreign Language Anxiety in a Spanish University Setting: Interpersonal Differences. Revista-psicodidactica, 17(1), 5-26.

Awan, R., Azher, M., Anwar, M. \& Naz, A. (2010). An Investigation Of Foreign Language Classroom Anxiety And Its Relationship With Students ${ }^{\text {ee }}$ Achievement. Journal of College Teaching \& Learning, 7(11), 33-40.

Aydin, S. (2008). An investigation on language anxiety and fear of negative evaluation among Turkish EFL learners. Asian EFL Journal. 30(1),421-444.

Baran-Lucarz, M. (2013). Foreign language pronunciation and listening anxiety- a preliminary study. In E. Piechurska-Kuciel \& E. SzymańskaCzaplak (eds), Language in Cognition and Affect, Second Language Learning and Teaching. Springer-Verlag Berlin Heidelberg.

Cabansag, J. (2013). English Language Anxiety and Reading Comprehension Performance of College Students in a State University. Journal of Arts, Science \& Commerce, 4(4), 20-31.

Chan, D. \& Wu, G. (2004). A Study of Foreign Language Anxiety of EFL Elementary School Students in Taipei County. Journal of National Taipei Teachers College, 17(2), 287-320.

Chiang, M. (2012). The Relationship Between Foreign Language Anxiety and Foreign Language Speaking Proficiency Among Elementary School Students in Taiwan. Doctoral dissertation, Ming Chuan University.

Gardner, R., \& MacIntyre, P. (1993). A student's contribution to second language learning. Part II: affect variables. Language Teaching 26, 1-11.

Ghonsooly, B. (2012). The Relationship between EFL Learners ${ }^{e e}$ Reading Anxiety Levels and Their Metacognitive Reading Strategy Use. International Journal of Linguistics, 4(3), 333-351. 
Gkonou, C. (2011). Anxiety over EFL speaking and writing: A view from language classrooms. Studies in Second Language Learning and Teaching, 1(2), 267-281.

Golchi, M. (2012). Listening Anxiety and Its Relationship with Listening Strategy Use and Listening Comprehension among Iranian IELTS Learners. International Journal of English Linguistics, 2(4), 115- 128.

Horwitz, E. \& Young, D. (1991). Language anxiety: From theory and research to classroom implications. Englewood Cliffs, NJ: Prentic Hall.

Horwitz, E., Horwitz, M. B., \& Cope, J. A. (1986). Foreign language classroom anxiety. The Modern Language Journal, 70(2), 125-132.

Horwitz, E., Tallon, M. \&Luo, H. (2010). Foreign Language Anxiety. In J. Cassady (Eds.), Anxiety in Schools: The causes, Consequences, and Solutions for Academic Anxieties (pp. 96-115). New York: Peter Lang Publishing, Inc.

Huang, Q. (2012). Study on Correlation of Foreign Language Anxiety and English Reading Anxiety. Theory and Practice in Language Studies, 2(7),1520-1525.

Hussain, M., Shahid, S. \& Zaman, A. (2011). Anxiety and Attitude Of Secondary School Students Towards Foreign Language Learning. Procedia Social and Behavioral Sciences, 29, 583-590.

Jafarigohar, M. \&Behrooznia, S. (2012). The Effect of Anxiety on Reading Comprehension among Distance EFL Learners. International Education Studies, 5(2), 159-174.

Javid, C. (2014). Measuring Language Anxiety in an EFL Context. Journal of Education and Practice, 5(25), 180-192.

Jebreil, N., Azizifar, A., Gowhary, H. \& Jamalinesari, A. (2015). Study on Writing Anxiety among Iranian EFL Students. International Journal of Applied Linguistics \& English Literature, 4(2), 68-72.

Jen, C. (2003). Anxiety in English language classrooms: An investigation of Taiwanese secondary school students' foreign language anxiety in four classroom contexts. Master's thesis. University of Bristol, UK.

Kamaruddin, S. \& Abdullah, N. (2015). Language Anxiety Among University Students: Causal Factors and Coping Strategies. Proceeding Kuala Lumpur International Communication, Education, Language and Social Sciences 1 (KLiCELS1), 6-7 June, Kuala Lumpur, Malaysia.

Lam, J. (2009). The Independent Learner: A Practical Guide to Learning a Foreign Language at Home from Scratch to Functional. North Carolina: Lulu Press Inc.

Lian, L. \&Budin, M. (2014). Investigating the Relationship between English Language Anxiety and the Achievement of School based Oral English Test among Malaysian Form Four Students. International Journal of Learning, Teaching and Educational Research, 2(1), 67-79. 
Liebert, R., \& Morris, L. (1967). Cognitive and emotional components of test anxiety: A distinction and some initial data. Psychological Reports, 20, 975-978.

Liu , H. (2012). Understanding EFL Undergraduate Anxiety in Relation to Motivation, Autonomy, and Language Proficiency. Electronic Journal of Foreign Language Teaching, 9(1), 123-139.

Mahmoodzadeh, M. (2013). Investigating foreign language anxiety in Iranian classrooms: The effect of gender. International Journal of Research Studies in Language Learning, 2(1), 61-70.

Marzec-Stawiarska, M. (2015). Investigating Foreign Language Speaking Anxiety Among Advanced Learners of English. In M. Pawlak\& E. WaniekKlimczak (Eds.), Issues in Teaching, Learning and Testing Speaking in a Second language (pp.103-120). Berlin: Springer.

Mesri, F. (2012). The Relationship between Gender and Iranian EFL Learners' Foreign Language Classroom Anxiety (FLCA). International Journal of Academic Research in Business and Social Sciences, 2(6), 147156.

Mohd. Zin, Z. \& Rafik-Galea, S. (2010). Anxiety and Academic Reading Performance among Malay ESL Learners. Pan-Pacific Association of Applied Linguistics 14(2), 41-58.

Muhaisen, M. \& Al-Abed Al-Haq, F. (2012). An Investigation of the Relationship Between Anxiety and Foreign Language Learning Among 2nd Secondary Students in Second Amman Directorate of Education. International Journal of Humanities and Social Science, 2(6), 226-240.

Naghadeh, s., Naghadeh, M., Kasraey, S., Maghdour, H., Kasraie, S. \&Naghadeh, N. (2014). The Relationship between Anxiety and Iranian EFL Learners' Narrative Writing Performance. International Journal of Psychology and Behavioral Research, 3(6), 602-609.

Nahavandi, N \& Mukundan, J. (2013). Foreign Language Learning Anxiety among Iranian EFL learners Along Gender and Different Proficiency Levels. Language in India, 13(1), 133-161.

Negari, G. \& Rezaabadi, O. (2012). Too Nervous to Write? The Relationship between Anxiety and EFL Writing. Theory and Practice in Language Studies, 2(12), 2578-2586.

Price, M. L. (1991). The subjective experience of foreign language anxiety: Interview with highly anxious students. In E. Horwitz\& D. Young (Eds.), Language anxiety: From theory and research to classroom implications. (pp.101-108). Englewood Cliffs, NJ: Prentice Hall.

Rezaei, M. \& Jafarib, M. (2014). Investigating the Levels, Types, and Causes of Writing Anxiety among Iranian EFL Students: A Mixed Method Design. International Conference on Current Trends in ELT, Procedia - Social and Behavioral Sciences, 98, 1545-1554. 
Riasati, M. (2011). Language Learning Anxiety from EFL Learners' Perspective. Middle-East Journal of Scientific Research 7 (6), 907-914.

Serraj, S. \& Noordin, N. (2013). Relationship among Iranian EFL Students' Foreign Language Anxiety, Foreign Language Listening Anxiety and Their Listening Comprehension. English Language Teaching, 6(5), 1-12.

Shabani, M. (2012). Levels and Sources of Language Anxiety and Fear of Negative Evaluation among Iranian EFL Learners. Theory and Practice in Language Studies, 2(11), 2378-2383.

Sharkawi, T (2009). Identity-Based Anxiety in the Language Classroom: A Case Study. In P. Wachob (Eds), Powder in the EFL Classroom Critical Pedagogy in the Middle East(pp.149-176). Newcastle: Cambridge Scholars Publishing.

Suleimenova , Z. (2012). Speaking Anxiety in a Kazakhstani Foreign Language Classroom. Sino-US English Teaching, 9(12),1766-1774.

Toth, Z. (2007). Predictors of Foreign-Language Anxiety: Examining the Relationship Between Anxiety and Other Individual Learner Variables. In J. Horvath \& N. Nikolov (Eds.), UPRT 2007: Empirical Studies in English applied linguistics (pp.123-148). Pecs: Lingua Franca Csoport.

Toth, Z. (2010). Foreign Language Anxiety and the Advanced Language Learner: A Study of Hungarian Students of English as a Foreign Language. Newcastle: Cambridge Scholars Publishing.

Tsai, Y. \& Li, Y. (2012). Test Anxiety and Foreign Language Reading Anxiety in a Reading-Proficiency Test. Journal of Social Sciences, 8(1): 95103.

Ucgun, D. (2011). The study on the writing anxiety levels of primary school 6, 7 and 8th year students in terms of several variables. Educational Research and Reviews, 6(7), 542-547.

Um, S., Tubsree, C. \& Surasin, J. (2013). Perception on English Reading Comprehension Anxiety of Third Year EFL Students at the Institute of Foreign Languages, Cambodia. HRD Journal, 4(1), 34-46.

Watson, D., \& Friend, R. (1969). Measurement of social-evaluative anxiety. Journal of Consulting and Clinical Psychology, 33, 448-457.

Williams, K. E. \& Andrade, M. (2008). Foreign Language Learning Anxiety in Japanese EFL University Classes: Causes, Coping, and Locus of Control. Electronic Journal of Foreign Language Teaching, 5(2),181-191.

Worde, R. (1998). An investigation of students' Perspectives on Foreign language anxiety. Doctoral Dissertation, George Mason University.

$\mathrm{Wu}, \mathrm{H}$. (2012). Anxiety and Reading Comprehension Performance in English as a Foreign Language. Asian EFL Journal, 13(2), 273-307.

Wu, K. (2010). The Relationship between Language Learners' Anxiety and Learning Strategy in the CLT Classrooms. International Education Studies, 3(1),174-191. 
Yahya, M. (2013). Measuring Speaking Anxiety Among Speech Communication Course Students at the Arab American University of Jenin (AAUJ). European Social Sciences Research Journal, 1(3), 229-248.

Yang, H. (2012). Language Anxiety: From the Classroom to the Community. English Teaching \& Learning, 36(4),1-36.

Young, D.J. (1991). Creating a low-anxiety classroom environment: What does language anxiety research suggest? The Modern Language Journal, 75, 426-439.

Zhang, H. (2011). A study on ESL writing anxiety among Chinese English majors - Causes, effects and coping strategies for ESL writing anxiety. Kristianstad University. 